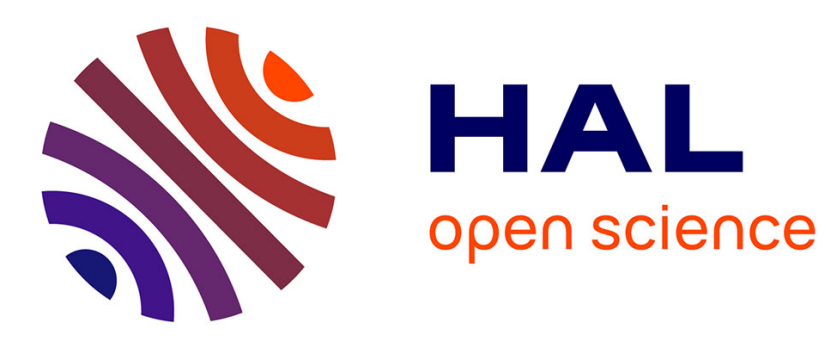

\title{
Highly Efficient Asymmetric Access to 1-Azaspiro[4.4]nonane Skeleton
}

Joelle Pérard-Viret, Loïc Planas, Jacques Royer, Mohamed Selkti, Alain Thomas

\section{- To cite this version:}

Joelle Pérard-Viret, Loïc Planas, Jacques Royer, Mohamed Selkti, Alain Thomas. Highly Efficient Asymmetric Access to 1-Azaspiro[4.4]nonane Skeleton. SYNLETT, 2002, 10, pp.1629-1632. $10.1055 / \mathrm{s}-2002-34232$. hal-03384985

\section{HAL Id: hal-03384985 https://hal.science/hal-03384985}

Submitted on 19 Oct 2021

HAL is a multi-disciplinary open access archive for the deposit and dissemination of scientific research documents, whether they are published or not. The documents may come from teaching and research institutions in France or abroad, or from public or private research centers.
L'archive ouverte pluridisciplinaire HAL, est destinée au dépôt et à la diffusion de documents scientifiques de niveau recherche, publiés ou non, émanant des établissements d'enseignement et de recherche français ou étrangers, des laboratoires publics ou privés. 


\title{
Highly Efficient Asymmetric Access to 1-Azaspiro[4.4]nonane Skeleton
}

Loïc Planas, ${ }^{\mathrm{a}}$ Joëlle Pérard-Viret, ${ }^{\mathrm{a}}$ Jacques Royer, ${ }^{* a}$ Mohamed Selkti, ${ }^{\mathrm{b}}$ Alain Thomas ${ }^{\mathrm{b}}$

a Laboratoire de Chimie Thérapeutique, UMR 8638, CNRS-Université Paris 5, 4 avenue de l'Observatoire, 75270 Paris cedex 06, France Fax +33(1)43291403; E-mail: royer@ pharmacie.univ-paris5.fr

b Laboratoire de Cristallographie, UMR 8015, CNRS-Université Paris 5, 4 avenue de l'Observatoire, 75270 Paris cedex 06, France

\begin{abstract}
Vinylogous Mukaiyama aldol type reaction of chiral non-racemic silyloxypyrroles followed by acidic treatment affords an efficient asymmetric access to 1-azaspiro[4.4]nonanes in high diastereoisomeric excess (up to 79\%).
\end{abstract}

Keys words: spiro compounds, asymmetric synthesis, ring expansion, rearrangement, pyrroles

1-Azaspiro[4.4]nonanes are building blocks difficult to access since the formation of quaternary spiro centers has always been a tricky exercise in organic synthesis. Nevertheless, methods to form a spiro center $\alpha$ to the nitrogen of a pyrrolidine have been developed, and they are based upon a wide variety of different methodologies. ${ }^{1}$ Among them, the use of radicals, ${ }^{1 \mathrm{a}}$ cycloadditions, ${ }^{\mathrm{b}}$ ring closure reaction, ${ }^{1 \mathrm{c}}$ palladium, ${ }^{1 \mathrm{~d}} \mathrm{~N}$-acyliminiums, ${ }^{1 \mathrm{e}}$ phenol oxidation $^{1 \mathrm{f}}$ and more recently the use of aluminium amide in domino reactions, ${ }^{1 \mathrm{~g}}$ have been described. It is noteworthy that only few of these methods are stereoselective ${ }^{1 b, e}$ and can be used for asymmetric synthesis of natural products containing this moiety.

We planned to develop a new asymmetric entry to 1-azaspiro[4.4]nonane, like the lactam $\mathbf{1}$, as a key intermediate in the synthesis of (-)-cephalotaxine 2 (Scheme 1).

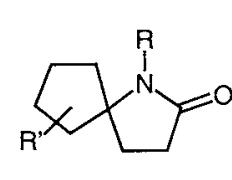

1

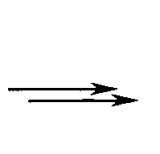

2

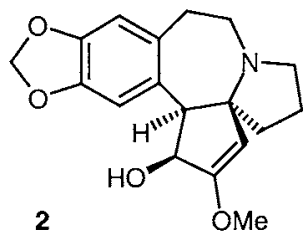

Scheme 1

We anticipated that this could be possible by the use of chiral non racemic $\alpha, \beta$-unsaturated $\gamma$-lactams 3 that we have been developing for some years. ${ }^{2}$ The possibility to diastereoselectively substitute $\gamma$-lactams 3 at the C-5 position with either an electrophile [via the silyloxypyrrole, path (a)] or a nucleophile [via a $N$-acyliminium, path (b), Scheme 2], permits to construct a quaternary spiro center at this carbon. As a matter of fact, the application of path (a) maintains the $\alpha, \beta$-unsaturation, allowing further use of path (b).

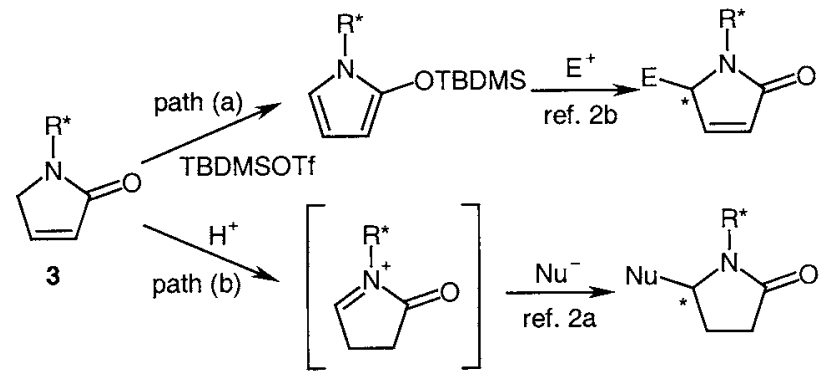

Scheme 2

The ring expansion of cyclobutanol derivatives giving rise to spiro compound via a semi-pinacol type reaction is known for a decade. It was well described by Paquette with dihydrofuran and tetrahydropyran derivatives, ${ }^{3}$ and recently, an example with piperidine compounds has been published. ${ }^{4}$ The key step for this reaction is the formation of a carbocation $\alpha$ to the carbinol of cyclobutanol, may it be an oxonium or a $N$-acyliminium.

This method appeared very attractive for us, since we anticipated that the cyclobutanol derivative required for the semi-pinacolic rearrangement should be the $\alpha, \beta$-unsaturated $\gamma$-lactam 6 (Scheme 3 ). It could be quite readily accessible by a vinylogous Mukaiyama aldol condensation of the silyloxypyrrole 5 with cyclobutanone.

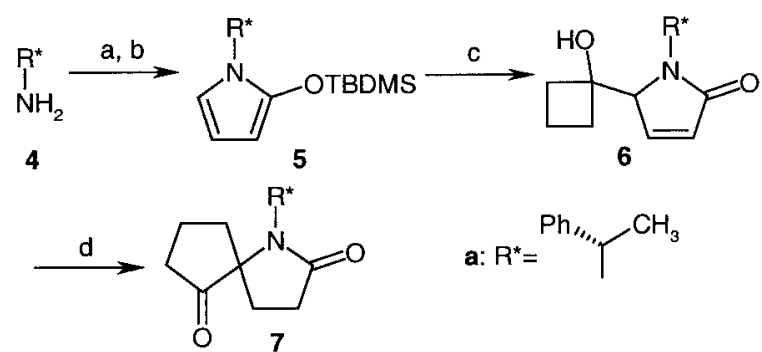

Scheme 3 Reagents and conditions: (a) 2,5-Dihydro-2,5-dimethoxyfuran, $\mathrm{HCl}, \mathrm{H}_{2} \mathrm{O}$, r.t.; (b) TBSOTf, $\mathrm{Et}_{3} \mathrm{~N}, \mathrm{CH}_{2} \mathrm{Cl}_{2}$, r.t.; (c) cyclobutanone, $\mathrm{BF}_{3} \cdot \mathrm{OEt}_{2}, \mathrm{CH}_{2} \mathrm{Cl}_{2},-78{ }^{\circ} \mathrm{C}$; (d) aq conc. $\mathrm{HCl}, \mathrm{CH}_{2} \mathrm{Cl}_{2}$, r.t.

In order to check this two step sequence we prepared silyloxypyrrole 5a derived from $\alpha$-methylbenzylamine 4a using the methodology already reported, namely condensation of $\mathbf{4 a}$ with dimethoxydihydrofuran to give 3a followed by TBDMSOTf treatment in presence of base. The expected compound (6a) was obtained in $85 \%$ yield and $83 \%$ diastereoisomeric excess when silyloxypyrrole 5a was reacted with cyclobutanone (Scheme 3$){ }^{5}$ 
The major isomer could be crystallized and allowed us to determine the absolute configuration of the new chiral center by X-ray analysis to be $S$ (Figure 1).

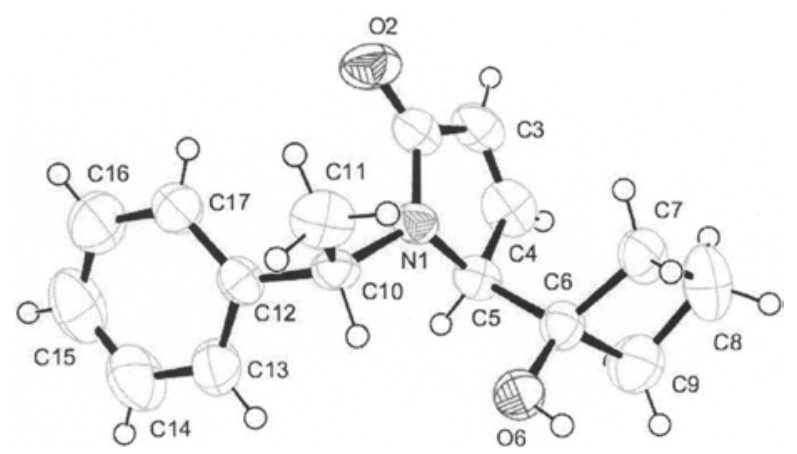

Figure 1 Crystal structure of $\mathbf{6 a}$, determined by X-ray. ${ }^{6}$

Then, 6a was placed under acidic conditions to achieve the ring expansion. Depending on the reaction conditions (Table 1), we observed either degradation or the elimination product or the expected product as a mixture of two diastereoisomers. The reaction could be carried out under different conditions but the best result was obtained by the use of concentrated hydrochloric acid in dichloromethane (Table 1, entry 7), as described for $N$-tosyliminiums by Dake's group. ${ }^{4}$

We can suggest that water was needed for this reaction, to ensure the spiro center formation instead of elimination (Scheme 4).

Table 1 Semi-pinacolic Rearrangement of Cyclobutanol Derivative 6a Under Various Acidic Conditions

\begin{tabular}{lllllc}
\hline Entry & Acid & Solvent & Temp & $\mathbf{7 a}^{\mathrm{a}}$ & $\mathbf{8 a}$ \\
\hline 1 & CSA & $\mathrm{CH}_{2} \mathrm{Cl}_{2}$ & r.t. & degradation \\
2 & PTSA & toluene & reflux & \multicolumn{2}{c}{ degradation } \\
3 & TfOH & $\mathrm{CH}_{2} \mathrm{Cl}_{2}$ & r.t. & degradation \\
4 & Amberlyst 15 & $\mathrm{CH}_{2} \mathrm{Cl}_{2}$ & r.t. & $70 \%$ & $30 \%$ \\
5 & Amberlyst 15 & toluene & r.t. & $75 \%$ & $25 \%$ \\
6 & Dowex 50X8-100 & $\mathrm{CH}_{2} \mathrm{Cl}_{2}$ & r.t. & $90 \%$ & $10 \%$ \\
7 & concd HCl & $\mathrm{CH}_{2} \mathrm{Cl}_{2}$ & r.t. & $>99 \%$ & $<1 \%$ \\
\hline
\end{tabular}

${ }^{\mathrm{a}}$ Product ratios are determined by integration of ${ }^{1} \mathrm{H}$ NMR spectra.

Unfortunately, despite the excellent chemical yield, the diastereoisomeric excess was modest (20\%), and we then decided to investigate other chiral auxiliaries in order to improve this result.

Various silyloxypyrroles 5a-e were prepared using our standard methodology from amines $\mathbf{4 a - e}$ in $41-73 \%$ overall yields. These silyloxypyrroles were engaged in the vinylogous Mukaiyama reaction followed by acidic treatment to give rise to the spiro compounds (Table 2).

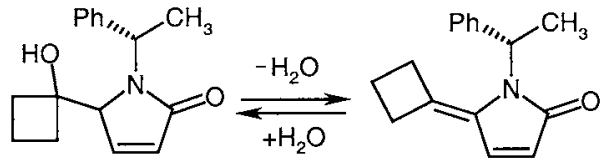<smiles>[Z10]CC1(N(C(=O)CC)[C@H](C)c2ccccc2)CCCC1=O</smiles>

Scheme 4

In all cases, this two steps sequence occurred in very high yield. Using phenylglycinol derivatives allowed us to improve the diastereoisomeric excess of the ring expansion reaction, but a real hit was obtained with $(S)$-1-(1-naphthyl)ethylamine. This chiral amine has already been used in asymmetric syntheses with good stereochemical results ${ }^{7}$ and is a suitable source of nitrogen and chirality for our target alkaloid. The diastereoisomeric excess could be further enhance from $74 \%$ to $79 \%$, operating at $0{ }^{\circ} \mathrm{C}$ instead of $20^{\circ} \mathrm{C}$, while time to reaction completion was raised from 2 hours to 9 hours. Nevertheless, at $-20^{\circ} \mathrm{C}$, no reaction occurred after 24 hours.

Table 2 Diastereoselectivity in the Rearrangement Reaction to 1Azaspiro[4.4]nonane Skeleton ${ }^{8}$

\begin{tabular}{|c|c|c|c|}
\hline Entry & Starting Amine & $\mathbf{6}^{\mathrm{a}, \mathrm{b}}$ Yield (de) $\%$ & $7,{ }^{\mathrm{b}}$ Yield (de) $\%$ \\
\hline 1 & $\mathrm{Ph}$ & $85(83)$ & $99(20)$ \\
\hline & & & \\
\hline 2 & 4b $\mathrm{Nh}_{2}$ & 84 (18) & 99 (40) \\
\hline 3 & 4c $\overbrace{\mathrm{NH}_{2}}^{\mathrm{Ph}_{1}}$ & $75(48)$ & $99(63)$ \\
\hline 4 & 4d ${ }_{\mathrm{N} \mathrm{H}_{2}}$ & $77(4)$ & $99(74-79)^{\mathrm{c}}$ \\
\hline $5^{\mathrm{d}}$ & $\begin{array}{c}\alpha-N a p h \\
4 \theta\end{array}$ & $62(30)$ & $99(68)$ \\
\hline
\end{tabular}

${ }^{a}$ Yield of isolated product.

${ }^{b}$ De determined by integration of corresponding signal in the ${ }^{1} \mathrm{H} N M R$ spectra of the crude reaction product.

${ }^{c}$ Reaction at $0{ }^{\circ} \mathrm{C}$.

${ }^{\mathrm{d}}$ Using racemic material.

Because of the improved de observed with O-substituted phenylglycinols, we envisioned the use of $O$-methylnaphthylglycinol (Table 2, entry 5). Different asymmetric syntheses of naphthylglycinol exist, ${ }^{9}$ but we preferred to prepare the more accessible racemic one. Thus, $4 \mathbf{e}$ was prepared in four steps from 1-napthaldehyde as shown in Scheme 5. 


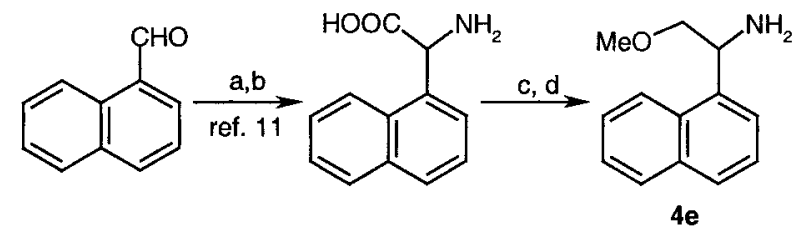

Scheme 5 Reagents and conditions: (a) $\mathrm{NaCN},\left(\mathrm{NH}_{4}\right)_{2} \mathrm{CO}_{3}$, EtOH/ $\mathrm{H}_{2} \mathrm{O} 50 / 50,50{ }^{\circ} \mathrm{C}, 24 \mathrm{~h}$; (b) $\mathrm{NaOH}, \mathrm{H}_{2} \mathrm{O}$, reflux, $2.5 \mathrm{~h}$; (c) LAH, THF (89\%); (d) KH, THF, overnight then MeI (75\%).

The amino acid was first obtained from the corresponding aldehyde through a modified Strecker synthesis as described. ${ }^{10}$ The reduction of the carboxylic acid function by $\mathrm{LiAlH}_{4}$ furnished the aminoalcohol which was regioselectively methylated ${ }^{11}(\mathrm{KH}, \mathrm{THF}, \mathrm{MeI})$ to give $4 \mathrm{e}$ in $67 \%$ for the two steps.

Unfortunenaly this new chiral auxiliary did not allow any improvement in the diastereoselectivity of the semi-pinacol rearrangement.

As suggested by the mechanism of the rearrangement and by the discrepancy between diastereoisomeric excesses of compounds 6 and 7 , the stereochemical information of compound 6 was lost in the semi-pinacolic rearrangement. This was definitively proved by placing each diastereoisomer of 5d, easily separable by crystallization, under the same experimental conditions (Scheme 6). We did not notice any measurable difference between the two crude products, proving that there was no kind of survival of the initial configuration. ${ }^{12}$ So, the chirality of the new center was only controlled by the chiral auxiliary, due to the free rotation in the intermediate $\mathrm{N}$-acyliminium.

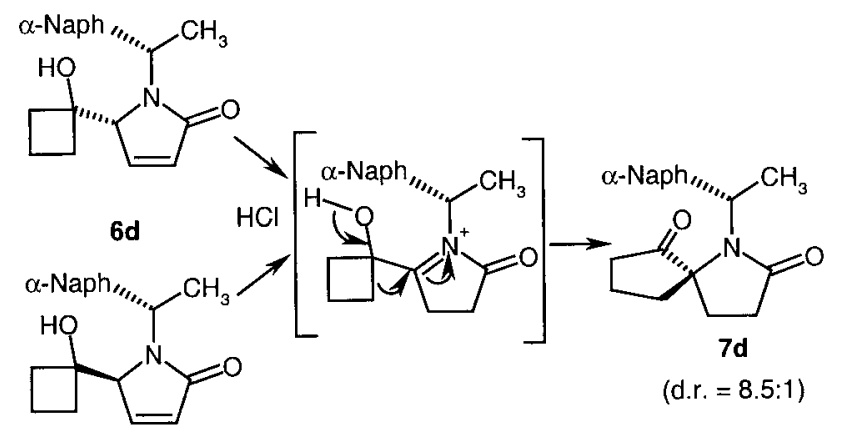

Scheme 6

Major diastereoisomer 7d could be easily separated through crystallization by triturating the crude product in ether $(68 \%$ of the diastereopure product could be obtained). We then derivatised it, on the way to determine the absolute configuration of the newly created spiro center (Scheme 7). First, the ketone was protected as the cyclic ketal 9d with ethylene glycol (77\% yield), and the latter was treated with lithium in liquid ammonia, ${ }^{13}$ to remove the chiral auxiliary. The ketal 10 (69\% yield) could be deprotected to obtain the simple spiro amide 11 in $86 \%$ yield.
This compound was described in the Nagasaka's cephalotaxine synthesis and the comparison of its optical rotation $\left([\alpha]_{\mathrm{D}}-64\right.$, lit. $\left.^{14}-68\right)$ allowed us to assign the $R$-configuration to the spiro center of $\mathbf{7 d}$. Following identical process, we also attributed the $R$-configuration to the spiro center of $7 \mathbf{c}$.

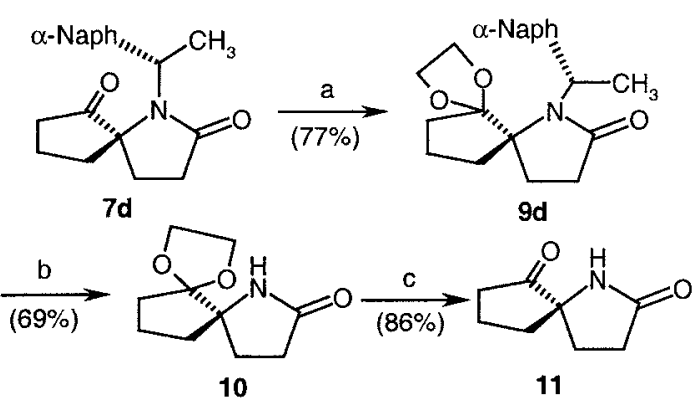

Scheme 7 Reagents and conditions: (a) Ethyleneglycol, PTSA, toluene, reflux; (b) $\mathrm{Li} / \mathrm{NH}_{3}$, ethanol, $-78{ }^{\circ} \mathrm{C}$; (c) $\mathrm{HOAc} / \mathrm{H}_{2} \mathrm{O} 50 / 50$, reflux.

Since the ring enlargement of cyclopentanol derivatives has been described with dihydrofuran compounds ${ }^{3}$ we envisaged this reaction starting with our $\gamma$-lactam.

The aldol product 12 was readily obtained from the silyloxypyrrole 5a under the same conditions as above, in good yield (78\%) and an excellent diastereoisomeric excess $(90 \%)$.

However, this compound did not undergo rearrangement reaction. By varying the conditions, we obtained either the elimination product or the product of hydrolysis of the $\mathrm{N}$ acyliminium moiety ${ }^{4}$ (Scheme 8).

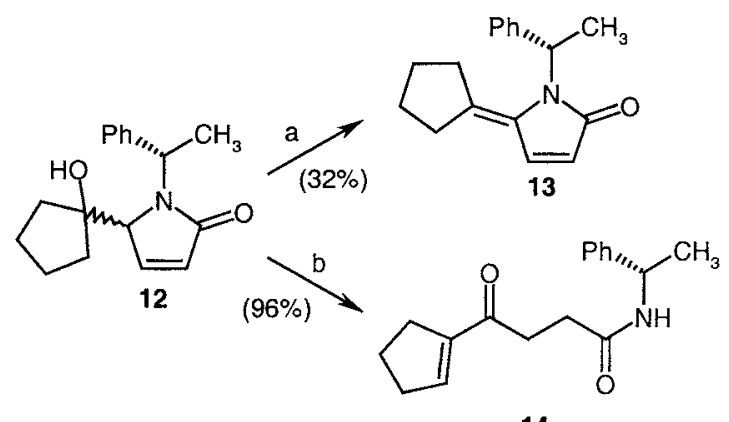

14

Scheme 8 Reagents and conditions: (a) Amberlyst $15, \mathrm{CH}_{2} \mathrm{Cl}_{2}$, r.t.; (b) concd $\mathrm{HCl}$, THF, r.t.

To summarize, we developed a highly efficient method for the diastereoselective formation of 1-azaspiro[4.4]nonanes, allowing us to construct the spiro bicyclic system of (-)-cephalotaxine. Work is on progress to complete a new asymmetric synthesis of (-)-cephalotaxine based on this methodology.

\section{Acknowledgement}

This work was supported by a grant from the M.E.N.R.T. 


\section{References}

(1) (a) Boivin, J.; Yousfi, M.; Zard, S. Tetrahedron Lett. 1997, 38, 5985. (b) Denmark, S. E.; Middleton, D. S. J. Org. Chem. 1998, 63, 1604. (c) Kende, A. S.; Hernando, J. I.; Milbank, J. B. J. Org. Lett. 2001, 3, 2505. (d) Doan, H. D.; Goré, J.; Vatèle, J.-M. Tetrahedron Lett. 1999, 40, 6765. (e) Bailey, P. D.; Morgan, K. M.; Smith, D. I.; Vernon, J. M. Tetrahedron Lett. 1994, 35, 7115. (f) Braun, N. A.; Ciufolini, M. A.; Peters, K.; Peters, E.-M. Tetrahedron Lett. 1998, 39, 4667. (g) Tietze, L. F.; Steck, P. L. Eur. J. Org. Chem. 2001, 4353.

(2) (a) Baussanne, I.; Chiaroni, A.; Husson, H.-P.; Riche, C.; Royer, J. Tetrahedron Lett. 1994, 35, 3931. (b) Baussanne, I.; Royer, J. Tetrahedron Lett. 1996, 37, 1213.

(c) Baussanne, I.; Royer, J. Tetrahedron Lett. 1998, 39, 845. (d) Dudot, B.; Micouin, L.; Baussanne, I.; Royer, J. Synthesis 1999, 688. (e) Baussanne, I.; Travers, C.; Royer, J. Tetrahedron: Asymmetry 1998, 9, 797. (f) Baussanne, I.; Chiaroni, A.; Royer, J. Tetrahedron: Asymmetry 2001, 12, 1219.

(3) (a) Paquette, L. A.; Negri, J. T.; Rogers, R. D. J. Org. Chem. 1992, 57, 3947. (b) Paquette, L. A.; Lanter, J. C.; Jonhston, J. N. J. Org. Chem. 1997, 62, 1702. (c) Paquette, L. A.; Kiney, M. J.; Dullweber, U. J. Org. Chem. 1997, 62, 1713.

(4) Fenster, M. D. E.; Patrick, B. O.; Dake, G. R. Org. Lett. 2001, 3, 2109.

(5) Typical Procedure for Silyloxypyrroles 5. To a solution of 2,5-dimethoxy-2,5-dihydrofuran (1 equiv) and chiral amine $\mathbf{4 a}, \mathbf{c}-\mathbf{e}$ (1 equiv) in water $(0.25 \mathrm{M})$ was added a concd solution of $\mathrm{HCl}$ (1.5 equiv). The mixture was stirred at r.t. for $3 \mathrm{~h}$ then neutralized with solid $\mathrm{NaHCO}_{3}$ and extract with $\mathrm{CH}_{2} \mathrm{Cl}_{2}$. The combined organic layers were dried over $\mathrm{MgSO}_{4}$ and the solvent distilled off. A red oil, mixture of the $\alpha, \beta$ and $\beta, \gamma$ unsaturated lactams was then obtained. tert-Butyldimethylsilyl triflate (1 equiv) was slowly added to a solution of either the crude product or the purified lactams (1 equiv) and $\mathrm{NEt}_{3}$ (2 equiv) in $\mathrm{CH}_{2} \mathrm{Cl}_{2}(0.1$ $\mathrm{M})$ and the mixture was stirred at r.t. for $1 \mathrm{~h}$. The solvent was evaporated under vacuum and the residue purified by filtration on a pad of alumina with a mixture of heptane and EtOAc. (Nota: silyloxypyrroles are used to be kept under argon at $\left.-20^{\circ} \mathrm{C}\right)$. Analyses for $5 \mathbf{d}:[\alpha]_{\mathrm{D}}{ }^{25}+11.7(c 0.69$, $\left.\mathrm{CH}_{2} \mathrm{Cl}_{2}\right) . \mathrm{Mp}=97^{\circ} \mathrm{C}$ (heptane-EtOAc). IR (KBr): $v=2929,2858,1560,1492,1438 \mathrm{~cm}^{-1} .{ }^{1} \mathrm{H}$ NMR $(300 \mathrm{MHz}$, $\left.\mathrm{CDCl}_{3}\right): \delta=-0.05(\mathrm{~s}, 3 \mathrm{H}), 0.23(\mathrm{~s}, 3 \mathrm{H}), 0.80(\mathrm{~s}, 9 \mathrm{H}), 1.89$ $(\mathrm{d}, J=7.0 \mathrm{~Hz}, 3 \mathrm{H}), 5.31(\mathrm{dd}, J=2.0,3.6 \mathrm{~Hz}, 1 \mathrm{H}), 6.01(\mathrm{t}$, $J=3.5 \mathrm{~Hz}, 1 \mathrm{H}), 6.16(\mathrm{q}, J=7.0 \mathrm{~Hz}, 1 \mathrm{H}), 6.35(\mathrm{dd}, J=1.9$, $3.4 \mathrm{~Hz}, 1 \mathrm{H}), 7.10(\mathrm{~d}, J=7.2 \mathrm{~Hz}, 1 \mathrm{H}), 7.42(\mathrm{t}, J=7.9 \mathrm{~Hz}$, $1 \mathrm{H}), 7.50-7.55(\mathrm{~m}, 2 \mathrm{H}), 7.77(\mathrm{~d}, J=8.3 \mathrm{~Hz}, 1 \mathrm{H}), 7.88(\mathrm{~d}$, $J=7.4 \mathrm{~Hz}, 1 \mathrm{H}), 8.08(\mathrm{~d}, J=8.0 \mathrm{~Hz}, 1 \mathrm{H}) .{ }^{13} \mathrm{C} \mathrm{NMR}$ $\left(75 \mathrm{MHz}, \mathrm{CDCl}_{3}\right): \delta=-5.0,-4.6,18.2,21.4,25.7,49.5$, $87.7,105.2,109.8,123.2,125.8,126.5,128.1,129.1,131.0$, 134.1, 139.7, 142.2. HRMS (CI, $\left.\mathrm{NH}_{3}\right): \mathrm{m} / z$ calcd for $\mathrm{C}_{22} \mathrm{H}_{30} \mathrm{NOSi}\left(\mathrm{MH}^{+}\right)$: 352.2097. Found: 352.2101. Typical Procedure for Cyclobutanols 6. To a solution of silyloxypyrrole 5a-e (1 equiv) in anhyd $\mathrm{CH}_{2} \mathrm{Cl}_{2}(0.15 \mathrm{M})$ with $3 \AA \mathrm{AS}$, under argon, was added cyclobutanone (or cyclopentanone) (1.6 equiv). After $15 \mathrm{~min}$ at r.t., the solution was cooled at $-78^{\circ} \mathrm{C}$ and $\mathrm{BF}_{3} \cdot \mathrm{OEt}_{2}$ (1.5 equiv) was added in the course of $15 \mathrm{~min}$. The solution was stirred at $-78{ }^{\circ} \mathrm{C}$ for $2 \mathrm{~h}$ and allowed to warm to $0{ }^{\circ} \mathrm{C}$. The reaction was quenched by addition of $\mathrm{H}_{2} \mathrm{O}$, the aq phase was separated and extracted with $\mathrm{CH}_{2} \mathrm{Cl}_{2}$. The organic phases were combined, dried over $\mathrm{Na}_{2} \mathrm{SO}_{4}$ and the solvent was removed under vacuum. The resulting oil was purified by flash chromatography.

Analyses for 6d: Minor diastereoisomer: $[\alpha]_{\mathrm{D}}{ }^{25}-264.1(c$ $\left.0.52, \mathrm{CHCl}_{3}\right) . \mathrm{Mp}=245^{\circ} \mathrm{C}\left(\mathrm{CH}_{2} \mathrm{Cl}_{2}\right)$. IR $(\mathrm{KBr}): v=3388$,
2976, 2937, $1660 \mathrm{~cm}^{-1}$. MS (CI, NH $)_{3}: \mathrm{m} / z=308\left(\mathrm{MH}^{+}\right)$, $238\left(\mathrm{MH}^{+}-\mathrm{C}_{4} \mathrm{H}_{6} \mathrm{O}\right) .{ }^{1} \mathrm{H}$ NMR $\left(300 \mathrm{MHz}, \mathrm{CDCl}_{3}\right): \delta=0.35$ $0.5(\mathrm{~m}, 1 \mathrm{H}), 1.01$ (s, $1 \mathrm{H}, \mathrm{D}_{2} \mathrm{O}$ exch.), 1.35-1.55 (m, $\left.2 \mathrm{H}\right)$, $1.55-1.70(\mathrm{~m}, 2 \mathrm{H}), 1.78(\mathrm{~d}, J=7.1 \mathrm{~Hz}, 3 \mathrm{H}), 1.85-2.00(\mathrm{~m}$, $1 \mathrm{H}), 4.25(\mathrm{t}, J=1.6 \mathrm{~Hz}, 1 \mathrm{H}), 6.30(\mathrm{~m}, 2 \mathrm{H}), 6.94(\mathrm{dd}$, $J=7.0,6.0 \mathrm{~Hz}, 1 \mathrm{H}), 7.40-7.60(\mathrm{~m}, 4 \mathrm{H}), 7.83(\mathrm{~d}, J=8.1 \mathrm{~Hz}$, $1 \mathrm{H}), 7.90(\mathrm{~d}, J=8.3 \mathrm{~Hz}, 1 \mathrm{H}), 8.23(\mathrm{~d}, J=8.4 \mathrm{~Hz}, 1 \mathrm{H}) .{ }^{13} \mathrm{C}$ NMR (75 MHz, DMSO): $\delta=17.7,24.4,36.2,40.6,55.1$, $74.8,81.3,128.5,130.3,130.8,131.7,132.9,134.3,134.5$, 136.1, 139.0, 143.5, 151.3, 177.6. Major diastereoisomer: $[\alpha]_{\mathrm{D}}{ }^{25}-13.8\left(\mathrm{c} 0.97, \mathrm{CHCl}_{3}\right) . \mathrm{Mp}=196-198^{\circ} \mathrm{C}\left(\mathrm{Et}_{2} \mathrm{O}\right) . \mathrm{IR}$ $(\mathrm{KBr}): v=3382,2977,2934,1658,1394 \mathrm{~cm}^{-1}$. MS (CI, $\left.\mathrm{NH}_{3}\right): m / z=308\left(\mathrm{MH}^{+}\right), 238\left(\mathrm{MH}^{+}-\mathrm{C}_{4} \mathrm{H}_{6} \mathrm{O}\right) .{ }^{1} \mathrm{H}$ NMR $(300$ $\left.\mathrm{MHz}, \mathrm{CDCl}_{3}\right): \delta=1.36(\mathrm{~m}, 1 \mathrm{H}), 1.80-2.10(\mathrm{~m}, 5 \mathrm{H}), 1.75$ $(\mathrm{s}, 1 \mathrm{H}), 1.86(\mathrm{~d}, J=7.0 \mathrm{~Hz}, 3 \mathrm{H}), 3.51(\mathrm{t}, J=1.5 \mathrm{~Hz}, 1 \mathrm{H})$, $6.07(\mathrm{q}, J=7.0 \mathrm{~Hz}, 1 \mathrm{H}), 6.28(\mathrm{dd}, J=1.6,6.0 \mathrm{~Hz}, 1 \mathrm{H}), 6.81$ $(\mathrm{dd}, J=1.8,6.0 \mathrm{~Hz}, 1 \mathrm{H}), 7.47(\mathrm{~m}, 3 \mathrm{H}), 7.63(\mathrm{~m}, 2 \mathrm{H}), 7.84$ $(\mathrm{m}, 2 \mathrm{H}) .{ }^{13} \mathrm{C}$ NMR $\left(75 \mathrm{MHz}, \mathrm{CDCl}_{3}\right): \delta=13.6,19.1,31.9$, $36.2,49.0,69.6,75.9,123.2,125.2,125.8,126.1,127.3$, 128.5, 129.1, 129.2, 132.0, 134.0, 136.2, 145.7, 173.3. Anal. Calcd for $\mathrm{C}_{20} \mathrm{H}_{21} \mathrm{NO}_{2}: \mathrm{C}, 78.15 ; \mathrm{H}, 6.89 ; \mathrm{N}, 4.56$. Found: $\mathrm{C}$, 78.03; H, 7.06; N, 4.60 .

(6) The crystal structure has been deposited at the Cambridge Crystallographic Data Centre; deposition number CCDC 180815.

(7) (a) Kuehne, M. E.; Matson, P. A.; Bornmann, W. G. J. Org. Chem. 1991, 56, 513. (b) Ishibashi, H.; Fuke, Y.;

Yamashita, T.; Ikeda, M. Tetrahedron: Asymmetry 1998, 9, 797.

(8) Typical Procedure for Spiro Compounds 7.

To a solution of cyclobutanol $\mathbf{6 a}-\mathbf{e}$ (1 equiv) in $\mathrm{CH}_{2} \mathrm{Cl}_{2}(0.05$ M) was added concd aq $\mathrm{HCl}\left(1.5\right.$ equiv). After $9 \mathrm{~h}$ at $0{ }^{\circ} \mathrm{C}$, the solvent was removed under vacuum. The crude product was redissolved twice in $\mathrm{CH}_{2} \mathrm{Cl}_{2}$ and reevaporated to eliminate trace amount of acid.

Analyses for 7d (cristallyzed from $\mathrm{Et}_{2} \mathrm{O}$ ): $[\alpha]_{\mathrm{D}}{ }^{25}-48.4$ (c 1.04, $\left.\mathrm{CHCl}_{3}\right) . \mathrm{Mp}=140{ }^{\circ} \mathrm{C}\left(\mathrm{Et}_{2} \mathrm{O}\right)$. IR $(\mathrm{KBr}): v=2968$, $1750,1679,1380,1347,780 \mathrm{~cm}^{-1}$. MS (CI, $\left.\mathrm{NH}_{3}\right): \mathrm{m} / z=308$ $\left(\mathrm{MH}^{+}\right),{ }^{1} \mathrm{H}$ NMR $\left(400 \mathrm{MHz}, \mathrm{CDCl}_{3}\right): \delta=1.07-1.17$ (m, 2 H), $1.34-1.55(\mathrm{~m}, 2 \mathrm{H}), 1.62$ (ddd, $J=6.5,8.5,12.3 \mathrm{~Hz}$, $1 \mathrm{H}), 1.67$ (d, $J=7.0 \mathrm{~Hz}, 3 \mathrm{H}), 1.87$ (ddd, $J=9.5,11.6,18.9$ $\mathrm{Hz}, 1 \mathrm{H}), 1.93$ (ddd, $J=6.8,8.9,12.3 \mathrm{~Hz}, 1 \mathrm{H}$ ), 2.23 (dd, $J=6.1,18.9 \mathrm{~Hz}, 1 \mathrm{H}), 2.43$ (dd, $J=6.8,8.5,16.8 \mathrm{~Hz}, 1 \mathrm{H}$ ), 2.53 (ddd, $J=6.5,8.9,16.8 \mathrm{~Hz}, 1 \mathrm{H}), 6.25(\mathrm{q}, J=7.1 \mathrm{~Hz}$, $1 \mathrm{H}), 7.30-7.60(\mathrm{~m}, 4 \mathrm{H}), 7.83(\mathrm{~d}, J=9.7 \mathrm{~Hz}, 1 \mathrm{H}), 7.79(\mathrm{~d}$, $J=7.6 \mathrm{~Hz}, 1 \mathrm{H}), 8.00(\mathrm{~d}, J=8.3 \mathrm{~Hz}, 1 \mathrm{H}) .{ }^{13} \mathrm{C} \mathrm{NMR}(75$ $\left.\mathrm{MHz}, \mathrm{CDCl}_{3}\right): \delta=7.8,18.9,29.0,31.7,32.3,35.7,47.5$, 72.3, 124.0, 125.1, 125.9, 126.3, 127.2, 129.1, 129.3, 132.7, 133.9, 136.1, 175.7, 217.0. Anal. Calcd for $\mathrm{C}_{20} \mathrm{H}_{21} \mathrm{NO}_{2}$ : C, 78.15; H, 6.89; N, 4.56. Found: C, 77.96; H, 7.15; N, 4.41.

(9) (a) Kawasaki, K.; Kastsuki, T. Tetrahedron 1997, 53, 6337. (b) Reddy, K. L.; Dress, K. R.; Sharpless, K. B. Tetrahedron Lett. 1998, 39, 3667. (c) Takacs, J. M.; Jaber, M. R.; Vellekoop, A. S. J. Org. Chem. 1998, 63, 2742.

(10) Kukolja, S.; Draheim, S. E.; Pfeil, J. L.; Cooper, R. D. G.; Graves, B. J.; Holmes, R. E.; Neel, D. A.; Huffman, G. W.; Webber, J. A.; Kinnick, M. D.; Vasileff, R. T.; Foster, B. J. J. Med. Chem. 1985, 28, 1886.

(11) Meyers, A. I.; Pointdexter, G. S.; Birch, Z. J. Org. Chem. 1978, 43, 892 .

(12) For a review about the memory of chirality: Fuji, K.; Kawabata, T. Chem.-Eur. J. 1998, 4, 373.

(13) Baussanne, I.; Schwardt, O.; Royer, J.; Pichon, M.; Figadère, B.; Cavé, A. Tetrahedron Lett. 1997, 39, 845.

(14) Nagasaka, T.; Sato, H.; Seaki, S.-I. Tetrahedron: Asymmetry 1997, 8, 191 . 